\title{
Increased cave use by butterflies and moths: a response to climate warming?
}

\author{
Otto Moog (10 ${ }^{1}$, Erhard Christian (10) ${ }^{2 *}$, and Rudolf Eis ${ }^{3}$ \\ ${ }^{1}$ Institute of Hydrobiology and Aquatic Ecosystem Management, University of Natural Resources and Life Sciences, Gregor Mendel 33 Str., 1180 Vienna, Austria \\ ${ }^{2}$ Institute of Zoology, University of Natural Resources and Life Sciences, Gregor Mendel 33 Str., 1180 Vienna, Austria \\ ${ }^{3}$ Waldegg 9a, 2754 Waldegg, Austria
}

\begin{abstract}
Between 2015 and 2019, the list of Lepidoptera from "cave" habitats (i.e., proper caves, rock shelters and artificial subterranean structures) in Austria grew from 17 to 62 species, although the effort of data collection remained nearly constant from the late 1970s onwards. The newly recorded moths and butterflies were resting in caves during daytime in the the warm season, three species were also overwintering there. We observed Catocala elocata at 28 cave inspections, followed by Mormo maura (18), Catocala nupta (7), Peribatodes rhomboidaria, and Euplagia quadripunctaria (6). More than half of the species have been repeatedly observed in caves in Austria or abroad, so their relationship with such sites is apparently not completely random. Since the increase of records in Austria coincided with a considerable rise in the annual number of hot days (maximum temperatures $\geq 30^{\circ} \mathrm{C}$ ) from 2015 onwards, we interpret the growing inclination of certain Lepidoptera towards daytime sheltering in caves as a behavioral reaction to climate warming.
\end{abstract}

Keywords: Lepidoptera, cave use, diurnal retreat, refuge-site preference, climate change

Received 22 October 2020; Revised 26 December 2020; Accepted 29 December 2020

Citation: Moog O., Christian E. and Eis R., 2021. Increased cave use by butterflies and moths: a response to climate warming? International Journal of Speleology, 50 (1), 15-24. Tampa, FL (USA) ISSN 0392-6672 https://doi.org/10.5038/1827-806X.50.1.2361

\section{INTRODUCTION}

In most cave fauna surveys butterflies and moths are underrepresented except for a handful of common subtroglophile species such as Scoliopteryx libatrix and Triphosa dubitata. This shortcoming pertains particularly to species that sporadically use caves and cave-like spaces for sheltering during daytime. The reason is double: Cave mouths and rock shelters are not in permanent darkness, hence many biospeleologists do not understand them as subterranean habitats (Culver \& Pipan 2009, Mammola et al. 2019). And, second, trogloxenes (sensu Sket 2008) have been largely neglected as irrelevant vagrants.

The list of Austrian "cave Lepidoptera" grew only slightly from 13 to 17 species in three deacades after the last compilation (Christian \& Moog, 1982). During that period, vast numbers of zoological cave inspections by the present authors yielded no further lepidopteran species record from a cave: the inventory appeared fairly complete. Thus it was unexpected when we observed, in mid-summer of 2015, two specimens of the tiger moth Euplagia quadripunctaria in a cave south of Vienna (Christian et al., 2017). Daytime sheltering in caves of this species had been reported from warmer climate regions but not from Central Europe. Two weeks later we met four specimens of Catocala elocata resting in a shallow cave in Eisenstadt (Burgenland), also the first such observation in Austria. From 2015 to 2019 we eventually found 45 lepidopteran species for the first time in subterranean cavities. In the present paper we compile all butterfly and moth species from Austrian caves and present those recorded for the first time in more detail. We specify the respective type of cave use and suggest a possible driver behind the evidently increasing attractivity of caves for Lepidoptera, namely the annual number of hot days as a consequence of climate warming.

\section{MATERIALS AND METHODS}

Data come chiefly from protocols of long-term cave inspections by two of us (OM \& EC) in eastern Austria (Burgenland, Lower Austria, Vienna) and occasional inspections in other provinces (Table 1). Inspections took place in daylight. A few records (verified by us) have been contributed by speleologists. Both local and temporal inspection density was highest along the eastern Alps boundary and in the hill ranges 
east of the Vienna Basin, at elevations from the planar to the submontane life zone. A round dozen of localities were inspected once or several times a year, the rest sporadically. Habitats included natural objects such as proper caves (Curl, 1964), shelter caves and spacious rock overhangs, as well as manmade structures such as air raid shelters, mines, tunnels and river underpasses. Natural and artificial underground spaces are collectively termed "caves" hereafter. According to Trimmel (1968) we let a cave begin at the eaves line, i.e., the horizontal projection of the edge of the rock that roofs the cave mouth. In artificial objects rock was sometimes replaced by a brick or concrete lining.

Lepidoptera were identified in place or determined on the basis of in situ photographs. Moths without distinct external features were taken to the laboratory for closer inspection. Specimens that required genital dissection were stored deep-frozen until examination by P. Buchner, who posted several photos and data on the Lepiforum web pages. Locations are detailed in Table 1.

Table 1. Locations of Lepidoptera reported for the first time from caves in Austria. Left column: Token with indication of the state (B: Burgenland, C: Carinthia, L: Lower Austria, S: Styria, T: Tyrol, U: Upper Austria, V: Vienna). Objects registered in the Austrian cave cadastre are designated by the full cadastral number (e.g., 1917/4); for any other object the appropriate cadastral area is stated (e.g., 1917/-).

\begin{tabular}{|c|c|c|c|c|c|}
\hline & Location & $\begin{array}{l}\text { Type, Cadastral } \\
\text { area or cad. \# }\end{array}$ & Municipality & Geogr. coord. MGI $\left[{ }^{\circ} \mathbf{N},{ }^{\circ} \mathbf{E}\right]$ & $\begin{array}{c}\text { Altitude } \\
\text { [m asl] }\end{array}$ \\
\hline V1 & Schreiberbach & Underpass, 1917/- & Vienna & $48.2590,16.3518$ & 215 \\
\hline V2 & Krapfenwaldbach & Underpass, 1917/- & Vienna & $48.2669,16.3319$ & 330 \\
\hline V3 & Nesselbach „B 1935“ & Brook tunnel, 1917/- & Vienna & $48.2688,16.3197$ & 375 \\
\hline V4 & Nameless headwater & Brook culvert, 1917/- & Vienna & $48.2747,16.3217$ & 425 \\
\hline V5 & Gspöttgraben & Underpass, 1917/- & Vienna & $48.2571,16.3139$ & 305 \\
\hline V6 & Tunnel to artesian well & Brick vault, 1917/- & Vienna & $48.2436,16.3556$ & 185 \\
\hline L1 & Kaltenleutgebener Höhle & Cave, $1917 / 4$ & Kaltenleutgeben & $48.1243,16.2185$ & 325 \\
\hline L2 & Merkurhöhle & Cave, $1917 / 5$ & Kaltenleutgeben & $48.1243,16.2182$ & 325 \\
\hline L3 & Loess cellar Rehgraben & Cellar, 6848/- & Langenzersdorf & $48.3910,16.3643$ & 205 \\
\hline L4 & Piesting culvert under L 157 & River culvert, 1921/- & Tattendorf & $47.9318,16.3322$ & 225 \\
\hline L5 & Marienbründl & Well house, 1921/- & Moosbrunn & $48.0147,16.4749$ & 180 \\
\hline L6 & Hochbergkeller & Cellar, cave, 1915/- & Perchtoldsdorf & $48.1154,16.2676$ & 265 \\
\hline L7 & Excentriqueshöhle & Cave, $1815 / 37$ & Kaltenleutgeben & $48.1219,16.2244$ & 348 \\
\hline L8 & Gaisberghöhle & Cave, $1815 / 6$ & Kaltenleutgeben & $48.1118,16.1992$ & 476 \\
\hline L9 & Östliche Mistelhöhle & Cave, $1915 / 13$ & Maria Enzersdorf & $48.0877,16.2764$ & 305 \\
\hline L10 & Westliche Mistelhöhle & Cave, $1915 / 14$ & Maria Enzersdorf & $48.0877,16.2763$ & 305 \\
\hline L11 & Einödhöhle & Cave, $1914 / 6$ & Pfaffstätten & $48.0253,16.2368$ & 375 \\
\hline L12 & Hinterbrühlerhöhle & Cave, $1914 / 13$ & Hinterbrühl & $48.0823,16.2424$ & 305 \\
\hline L13 & Hinterbrühler Felsentor & Cave, $1914 / 12$ & Hinterbrühl & $48.0834,16.2449$ & 300 \\
\hline L14 & Schüttkastenhöhle & Cave, $1913 / 14$ & Heiligenkreuz & $48.0554,16.1305$ & 315 \\
\hline L15 & Tunnel close to Lourdes grotto & Artificial tunnel, 1913/- & Heiligenkreuz & $48.0553,16.1308$ & 310 \\
\hline L16 & Wasserglurn & Adit and cave, 1913/12 & Heiligenkreuz & $48.0311,16.1384$ & 285 \\
\hline L17 & Nameless small cave & Cave, 1912/- & Baden & $48.0116,16.2306$ & 295 \\
\hline L18 & Winschloch & Cave, 1912/35 & Baden & $48.0163,16.2271$ & 310 \\
\hline L19 & Harzberg sand tunnel no. 1 & Disused mine, 1911/- & Bad Vöslau & $47.9683,16.1943$ & 390 \\
\hline L20 & Harzberg sand tunnel no. 2 & Disused mine, 1911/- & Bad Vöslau & $47.9684,16.1942$ & 390 \\
\hline L21 & Schelmenloch & Cave, shelter, 1911/41 & Bad Vöslau & $47.9819,16.1985$ & 330 \\
\hline L22 & Schelmenloch cella & Rock tunnel, 1911/- & Bad Vöslau & $47.9819,16.1988$ & 330 \\
\hline L23 & Guglzipfhöhle & Cave, $1869 / 1$ & Berndorf & $47.9427,16.1120$ & 350 \\
\hline L24 & Höllturmhöhle & Cave, $1869 / 7$ & Wöllersdorf & $47.8681,16.1755$ & 355 \\
\hline L25 & Steinwand rock shelter & Deep overhang, 1818/- & Furth / Triesting & $47.9309,15.9439$ & 660 \\
\hline L26 & Steinwandklamm-Halbhöhle & Cave, $1868 / 47$ & Furth / Triesting & $47.9319,15.9485$ & 570 \\
\hline L27 & Wegkluft & Cave, $1868 / 49$ & Muggendorf & $47.9316,15.9444$ & 665 \\
\hline L28 & Türkenloch & Cave, $1868 / 4$ & Muggendorf & $47.9306,15.9452$ & 695 \\
\hline L29 & Pecherhöhle & Cave, $1868 / 3$ & Muggendorf & $47.9305,15.9451$ & 695 \\
\hline L30 & Hofmannshöhle & Cave, $1864 / 8$ & Wöllersdorf & $47.8557,16.1460$ & 500 \\
\hline L31 & Trockenes Loch & Cave, $1836 / 34$ & Schwarzenbach & $47.9134,15.3743$ & 760 \\
\hline L32 & Templerhöhle & Cave, $2872 / 20$ & Seebenstein & $47.6966,16.1492$ & 415 \\
\hline L33 & Karnerhöhle & Cave, $2872 / 5$ & Pitten & $47.7171,16.1899$ & 380 \\
\hline L34 & Tunnel below Hainburg Castle & Air raid shelter, 2921/- & Hainburg & $48.1425,16.9467$ & 225 \\
\hline
\end{tabular}




\begin{tabular}{|c|c|c|c|c|c|}
\hline L35 & Danube bank tunnel no. 1 & Rock tunnel, 2921/- & Hainburg & $48.1537,16.9475$ & 145 \\
\hline L36 & Danube bank tunnel no. 2 & Rock tunnel, 2921/- & Hainburg & $48.1541,16.9478$ & 145 \\
\hline L37 & Rötelsteinhöhle & Rock tunnel, 2921/6 & Hainburg & $48.1534,16.9606$ & 335 \\
\hline B1 & Ludlloch & Cave, 2911/1 & Winden am See & $47.9707,16.7558$ & 190 \\
\hline B2 & Hartllucke & Cave, 2911/38 & Eisenstadt & $47.8565,16.5274$ & 250 \\
\hline B3 & Kleine Hartllucke & Cave, 2911/39 & Eisenstadt & $47.8569,16.5275$ & 250 \\
\hline B4 & Flache Hartllucke & Cave, $2911 / 40$ & Eisenstadt & $47.8571,16.5275$ & 250 \\
\hline B5 & Johannesgrotte & Cave, $2911 / 25$ & Eisenstadt & $47.8633,16.5221$ & 290 \\
\hline B6 & Sulzbergschluf & Cave, 2911/43 & Stotzing & $47.8968,16.5312$ & 320 \\
\hline B7 & Kirchenhalbhöhle & Cave, 2911/44 & Stotzing & $47.8964,16.5310$ & 315 \\
\hline B8 & Sulzberghöhle & Cave, 2911/33 & Stotzing & $47.8970,16.5308$ & 310 \\
\hline B9 & Gliridenhöhle & Cave, $2911 / 34$ & Stotzing & $47.8966,16.5310$ & 315 \\
\hline $\mathrm{U} 1$ & Tunnel no. 3 & Rock tunnel, 1617/- & Ebensee & $47.7856,13.7619$ & 475 \\
\hline $\mathrm{U} 2$ & Tunnel no. 5 (Memorial site) & Rock tunnel, 1617/- & Ebensee & $47.7854,13.7615$ & 475 \\
\hline $\mathrm{S} 1$ & Grotte & Cave, $2763 / 2$ & Oberweg & $47.1618,14.6435$ & 900 \\
\hline $\mathrm{S} 2$ & Bärenhöhle im Hartelsgraben & Cave, $1714 / 1$ & Johnsbach & $47.5657,14.7101$ & 1325 \\
\hline $\mathrm{C} 1$ & Griffener Tropfsteinhöhle & Cave (show cave), 2751/1 & Griffen & $46.7045,14.7313$ & 485 \\
\hline $\mathrm{T} 1$ & Tunnel at Kaiseraufstieg & Artificial tunnel, 1312/- & Ebbs & $47.5934,12.1917$ & 605 \\
\hline $\mathrm{T} 2$ & Small cleft cave no. 1 & Cave, $1312 /-$ & Ebbs & $47.5935,12.1918$ & 610 \\
\hline T3 & Small cleft cave no. 2 & Cave, $1312 /-$ & Ebbs & $47.5931,12.1959$ & 650 \\
\hline $\mathrm{T} 4$ & Tischoferhöhle & Cave, $1312 / 1$ & Ebbs & $47.5929,12.1970$ & 605 \\
\hline T5 & Shelter 1 in Kundl Gorge & Cave, $1413 /-$ & Kundl & $47.4598,11.9904$ & 680 \\
\hline T6 & Shelter 2 in Kundl Gorge & Cave, $1413 /-$ & Kundl & $47.4489,11.9842$ & 670 \\
\hline $\mathrm{T} 7$ & Small cave in Kundl Gorge & Cave, $1413 /-$ & Wildschönau & $47.4445,11.9898$ & 645 \\
\hline T8 & Shelter 3 in Kundl Gorge & Cave, 1413/- & Wildschönau & $47.4441,11.9899$ & 665 \\
\hline
\end{tabular}

For convenience, any butterfly or moth observed in a cave is referred to as a cave lepidopteran, irrespective of its relationship to underground habitats. In order to distinguish random vagrants from more regular cave visitors it was assumed that repeated observations in domestic caves and the availability of records from foreign caves indicate a morethan-random relationship with this habitat. Three types of nonrandom cave use were distinguished: "Overwintering" lepidopterans move into caves from late summer on to spend there a period of dormancy until next springtime. "Deep diurnal retreat" pertains to species that were observed also in deeper parts of the cave and did tolerate some disturbance before they flew up. "Shallow diurnal retreat" pertains to species that were observed in the entrance zone and were more sensitive to disturbance (e.g., by the photo flash). For the distinction of the two types of daytime cave use in the warm season we analyzed the field notes with regard to resting position and behavior of lepidopterans from 471 underground sites. "Random" cave use was usually (and provisionally) attributed to species with a single subterranean record.

\section{RESULTS}

\section{Habitat use of previously published cave-visiting Lepidoptera}

In the first survey of extant cave animals of Austria, Strouhal \& Vornatscher (1975) listed seven overwintering Lepidoptera. Scoliopteryx libatrix (55.6\%), Triphosa dubitata (29.8\%), and Aglais io
(9.8\%) made up 95\% of the entries, followed by Triphosa sabaudiata, Alucita desmodactyla, Hypena rostralis, and Aglais urticae. Underground observations of these subtroglophile species in late summer are rather due to an early settling for winter than to mere daytime sheltering, e.g., Alucita desmodactyla in a Styrian cave (S1) on 07 Aug 2016 or Hypena rostralis in a brook tunnel in Vienna (V3) on 20 Aug 2017. Christian \& Moog (1982) added six cave moths with different cave use: Agonopterix curvipunctosa, Digitivalva pulicariae and Chloroclysta miata (overwintering); Camptogramma bilineata (diurnal retreat); Eugraphe sigma and Ligdia adustata (random). Cave observations of four lepidopteran species were published by speleologists: Harpella forficella (Nixloch, 1665/1, Ternberg, $770 \mathrm{~m}$ asl: Weichenberger, 1989), Entephria caesiata (Wildfrauenloch, 1563/12, Gosau, 1345 m asl: Fritsch, 2008) and Sunira circellaris (air raid shelter Rudolfstollen, Linz, $267 \mathrm{~m}$ asl: Fritsch et al., 2016) exhibit random cave use, Eupithecia undata (Salzofenhöhle, 1624/31, Grundlsee, $2055 \mathrm{~m}$ asl: Kerschbaum \& Pöll, 2010) has been reported from caves e.g., in Bulgaria (Guéorguiev \& Beron, 1962) and might occasionally use caves for resting during daytime. Our observations after 1982 (not presented here) largely corroborate the ecological assessment of the 17 species. We only add that Digitivalva pulicariae appears in east Austrian caves also during the warm season. Summer and winter observations are referable to consecutive generations of this micromoth, as reported from caves in Romania (Căpuşe \& Georgescu, 1962). 


\section{First records in Austrian caves}

Nineteen of the 45 newly recorded cave moth species have previously been reported from foreign caves. Chloroclysta siterata, Alucita huebneri, and Agonopterix heracliana were observed both overwintering and daytime sheltering on hot summer days, the remaining lepidopterans rested in caves exclusively during daytime in the warm season. Around one third (16 species) were repeatedly encountered in Austria. By far the highest number of observations pertain to Catocala elocata and Mormo maura (Table 2).

Table 2. Moth species repeatedly encountered in Austrian caves (2015-2019).

\begin{tabular}{|l|c|}
\hline \multicolumn{1}{|c|}{ Species } & $\begin{array}{c}\text { Encounters } \\
\text { Locations }\end{array}$ \\
\hline Catocala elocata & $28 / 21$ \\
\hline Mormo maura & $18 / 11$ \\
\hline Catocala nupta & $7 / 6$ \\
\hline Euplagia quadripunctaria & $6 / 6$ \\
\hline Peribatodes rhomboidaria & $6 / 6$ \\
\hline Alucita huebneri & $5 / 5$ \\
\hline Agonopterix heracliana & $5 / 5$ \\
\hline Mniotype satura & $5 / 5$ \\
\hline Philereme transversata & $5 / 5$ \\
\hline Erebia aethiops & $4 / 4$ \\
\hline Chloroclysta siterata & $3 / 3$ \\
\hline Lymantria dispar & $2 / 2$ \\
\hline Nudaria mundana & $2 / 2$ \\
\hline Parascotia fuliginaria & $2 / 2$ \\
\hline Hofmannophila pseudospretella & $2 / 1$ \\
\hline Nematopogon swammerdamella & $2 / 1$ \\
\hline
\end{tabular}

In the following, species are arranged in the order of their first cave record in Austria. Records from foreign countries are not intended to be exhaustive.

Mormo maura (Linnaeus, 1758) Old Lady, Noctuidae. Cave records from: Croatia (Jakšić, 2017); Bulgaria (Beshkov \& Langourov, 2004); Romania (Rákosy, 2004); Spain (Escolà, 1982; Pérez Fernández et al., 2012); France (Centelles Bascuas, 2015); Belgium (Turquin, 1994), England (Dacie, 1985 [in an old air raid shelter], Turquin, 1994); Italy (Fabbri, 2013; Mosconi, 2006; Sciarretta et al., 2006); Malta (Skinner \& Wilson, 2009). - Austria: Freinberghöhle, 1579/1, Linz, $275 \mathrm{~m}$ asl, 21 June 2007 (unpublished record kindly communicated by E. Fritsch). L7 (14 Aug 2016), L2 1 (20 July 2017, 11 July 2019), V3 (20 Aug 2017, 05 Aug 2018, 12 July 2019, 11 Aug 2019), V5 (07 Aug 2018), V6 (07 Aug 2018, 28 Aug 2018, 31 July 2019), L3 (11 Aug 2018), L15 (07 July 2019, 08 July 2019), L36 (04 Aug 2019), L24 (05 Aug 2019), L28 (10 Aug 2019), L4 (09 Sep 2019). The moths rested motionless solitarily or in groups of up to 15 , partly closely nestled with imbricate wings. - Cave use: Deep diurnal retreat.

Euplagia quadripunctaria (Poda, 1761) Jersey Tiger, Erebidae: Arctiinae. Cave records from: France (Braud \& Sardet, 2013); Italy (Fabbri \& Poletti, 2015); Greece (Bender, 1963). - Austria: L6 (16 July 2015), T1 (27 July 2018), T2 (27 July 2018) T4 (27 July 2018), L19 (02 Aug 2019), L29 (10 Aug 2019). - Cave use: Shallow diurnal retreat.
Catocala elocata (Esper, 1787) French Red Underwing, Erebidae. Cave records from: Bulgaria (Jakšić, 2017; Beshkov \& Petrov, 1996; Gueorguiev \& Beron, 1962; Beron, 1994); Italy (Malavasi, 2005); Spain (Calle, 1982). - Austria: B2 (02 Aug 2015, 12 July 2018), L18 (07 July 2018, 31 July 2018, 07 Aug 2018), L17 (07 July 2018), B5 (12 July 2018), V3 (04 Aug 2018, 05 Aug 2018), B8 (09 Aug 2018), B6 (09 Aug 2018), B7 (09 Aug 2018), L2 1 (10 Aug 2018), L1 (11 Aug 2018), L2 (11 Aug 2018), L3 (11 Aug 2018, 31 July 2019), L24 (11 Aug 2018), L9 (18 Aug 2018), L35 (04 Aug 2019), L36 (04 Aug 2019), L25 (10 Aug 2019), B8 (24 Aug 2019), B9 (24 Aug 2019), B2 (28 July 2019), L4 (30 Aug 2019, 02 Sep 2019, 04 Sep 2019). - Cave use: Shallow diurnal retreat.

Chloroclysta siterata (Hufnagel, 1767) Redgreen Carpet, Geometridae. Cave records from: Italy (Mosconi, 2011). Ebert (2001) assumed overwintering in the vegetation, because no winter observations in caves, cellars or tree holes were known. Meanwhile a cave record from Germany is available (Swabian Alb, 17 Feb 2013: Schön, 2020). - Austria: An underground record on 4 Apr 2019 suggests that $C$. siterata uses Austrian caves also for overwintering. - V3 (20 Aug 2017), L20 (4 Apr 2019), L30 (18 Aug 2019: 5 specimens). Cave use: Overwintering and deep diurnal retreat.

Alucita huebneri Wallengren, 1859, Alucitidae. Cave records from: Italy (Mosconi, 2011), Greece (Beshkov \& Wegner, 2004), France and Romania (Turquin, 1994), Romania (Rákosy, 2004). - Austria: All specimens were determined by P. Buchner, partly by genital preparation. The observation in early August indicates diurnal retreat. - L21 (29 Sept 2017), B1 (19 Oct 2017: 3 specimens), V4 (25 Dec 2017), L20 (5 Oct 2018), L24 (5 Aug 2019: 3 specimens). Cave use: Overwintering and deep diurnal retreat.

Agonopterix heracliana (Linnaeus, 1758), Elachistidae. Cave records from: Czech republic (overwintering in military bunkers: Dvořák, 2000, 2002); Germany (Dobat, 1978); France (Turquin, 1994); Belgium (Dethier \& Depasse, 2004). - Austria: L23 (16 Oct 2017); L34, L35, L36, L37 (4. Aug. 2019: several specimens in each object). Cave use: Overwintering and deep diurnal retreat.

Telechrysis tripuncta (Haworth, 1828) Treblespot Tubic, Elachistidae. Cave records from: no data. - Austria: L8 (20 May 2018). The three specimens from L8 were the first record of this species for Lower Austria (teste P. Huemer). Lepiforum contains a record from a small cave in the Weizklamm gorge, Styria, 13 June 2020, posted by H. Pichler. Cave use: Shallow diurnal retreat.

Amphipyra pyramidea (Linnaeus, 1758) Copper Underwing, Noctuidae: Amphipyrinae. Cave records from: Italy (Lopez, 1997; Mosconi, 2011); Croatia (Kučinič, 2002); England, in cellars (Young, 1997). - Austria: L14 (21 June 2018). Cave use: Shallow diurnal retreat.

Eccopisa effractella Zeller, 1848, Pyralidae. Cave records from: no data. - Austria: L5 (22 June 2018). The specimen was determined by means of microscopic and molecular methods (P. Buchner). Cave use: Random. 
Hofmannophila pseudospretella (Stainton, 1849)

Brown House Moth, Oecophoridae. Cave records from: Belgium (Dethier \& Depasse, 2004); Luxembourg (Werno et al., 2013); France (Lepesme, 1937); England (Macdonald, 1992). Also from Australia (Dew, 1963). - Austria: L24 (2 July 2018, 12 Aug 2018), det. P. Buchner. Each of the two specimens rested at least 20 $\mathrm{m}$ behind the cave entrance. Cave use: Deep diurnal retreat.

Naenia typica (Linnaeus, 1758) The Gothic, Noctuidae: Noctuinae. Cave records from: Germany, in a railway underpass (Hofsäß, n.d.). - Austria: L23 (3 July 2018). Cave use: Deep diurnal retreat.

Lymantria dispar (Linnaeus, 1758) Gypsy Moth, Erebidae: Lymantriinae. Cave records from: no data. - Austria: B2 (12 July 2018), B3 (12 July 2018). Cave use: Shallow diurnal retreat.

Horisme corticata (Treitschke, 1835), Geometridae. Cave records from: no data. - Austria: B2 (12 July 2018). Cave use: Random.

Philereme transversata (Hufnagel, 1767) Dark Umber, Geometridae. Cave records from: no data. Austria: B2 (12 July 2018), L3 (16 June 2019), L20 (21 June 2019), L21 (23 June 2019), B8 (29 July 2019). Cave use: Deep diurnal retreat.

Phragmatobia fuliginosa (Linnaeus, 1758) Ruby Tiger, Erebidae: Arctiinae. Cave records from: no data. Austria: L31 (21 July 2018, photo record K. Bürger). Cave use: Random.

Erebia aethiops (Esper, 1777) Scotch Argus, Nymphalidae. Cave records from: no data. According to Slamova et al. (2011), the butterflies nectar in the morning and spend the hottest daytime in the shade. - Austria: T3 (27 July 2018), T4 (27 July 2018), T7 (24 July 2019), T8 (24 July 2019). Cave use: Shallow diurnal retreat.

Peribatodes rhomboidaria (Denis \& Schiffermüller, 1775) Willow Beauty, Geometridae. Cave records from: no data. - Austria: V3 (4 Aug 2018), B8 (9 Aug 2018), L11 (20 Aug 2018), L10 (18 Sep 2018), L16 (10 June 2019), B3 (6 July 2019). Cave use: Shallow diurnal retreat.

Polygonia c-album (Linnaeus, 1758) Comma, Nymphalidae. Cave records from: no data. Wiklund \& Tullberg (2004) and Dvořák et al. (2009) agree that $P$. c-album does not overwinter in underground shelters. - Austria: B9 (9 Aug 2018, hottest day of the year). Cave use: Random.

Yponomeuta cf. cagnagella / sedella, Yponomeutidae. No reliable determination possible (the specimen was only photographed). - Austria: L3 (11 Aug 2018). Cave use: Random.

Eupithecia tripunctaria Herrich-Schäffer, 1852 White-spotted Pug, Geometridae. Cave records from: no data. - Austria: L3 (11 Aug 2018). Cave use: Random.

Timandra comae Schmidt, 1931 Blood Vein, Geometridae. Cave records from: Bulgaria (Jakšić, 2017). - Austria: L3 (11 August 2018). Cave use: Shallow diurnal retreat.

Borkhausenia fuscescens (Haworth, 1828) Small Dingy Tubic, Oecophoridae. Cave records from: no data. - Austria: L24 (12 Aug 2018), det. P. Buchner. Cave use: Random.
Mniotype satura (Denis \& Schiffermüller, 1775) Beautiful Arches, Noctuidae: Xyleninae. Cave records from: no data. - Austria: U1 (23 Aug 2018), U2 (23Aug 2018), C1 (19 Sep 2018: photo record M. Kropf); T6 (24 July 2019), B2 (28 July 2019). Cave use: Deep diurnal retreat.

Epinotia tenerana (Denis \& Schiffermüller, 1775) Nut Bud Moth, Tortricidae. Cave records from: no data. - Austria: U1 (23 Aug 2018). Cave use: Random (seeking rain shelter on that wet day?).

Phigalia pilosaria (Denis \& Schiffermüller, 1775) Pale Brindled Beauty, Geometridae. Cave records from: no data. - Austria: B8 (26 Apr 2019). Cave use: Random.

Adela reaumurella (Linnaeus, 1758) Green Longhorn, Adelidae. Cave records from: Belgium (Dethier \& Depasse, 2004). - Austria: B8 (26 Apr 2019). Cave use: Deep diurnal retreat.

Nematopogon swammerdamella (Linnaeus, 1758) Large Longhorn, Adelidae. Cave records from: no data. - Austria: B8 (26 Apr 2019, 29 July 2019). Cave use: Deep diurnal retreat.

Ectropis crepuscularia (Denis \& Schiffermüller, 1775) Engrailed, Geometridae. Cave records from: Russia (Mukhanov \& Kapralov, 2010). - Austria: B8 (26 Apr 2019). Cave use: Deep diurnal retreat.

Idaea aversata (Linnaeus, 1758) Riband Wave, Geometridae. Cave records from: no data. - Austria: L3 (16 June 2019). Cave use: Random.

Idaea dimidiata (Hufnagel, 1767) Single-dotted Wave, Geometridae. Cave records from: no data. Austria: L3 (16 June 2019). Cave use: Random.

Paratalanta hyalinalis (Hübner, 1796), Crambidae. Cave records from: no data. - Austria: L3 (16 June 2019). Cave use: Random.

Aglossa pinguinalis (Linnaeus, 1758) Large Tabby Moth, Pyralidae. Cave records from: Spain (Sánchez Piñero \& Pérez López, 1998); Belgium (Dethier \& Depasse, 2004); Italy (Sciarretta et al., 2006; Mosconi, 2011); Romania (Rákosy, 2004; Jakšić, 2017); Greece (Beron et al., 2011). - Austria: L24 (22 June 2019). Cave use: Deep diurnal retreat.

Nudaria mundana (Linnaeus, 1761) Muslin Footman, Erebidae: Arctiinae. Cave records from: Poland (Kocot-Zalewska \& Domagała, 2020); Germany (Alberti, 1938); Italy (Mosconi, 2011); France (Centelles Bascuas, 2015); Belgium (Sarlet, 1982; Dethier \& Depasse, 2004). Alberti (1938) reports on the "hasty refuge" of $N$. mundana moths into rock niches and caves during thunderstorms in Germany. Italian studies refer to this species as locally eutroglophile, because it can complete the full developmental cycle inside a cave (Zilli, 1992; Sciarretta et al., 2006). According to Dethier \& Depasse (2004), N. mundana is "sans doute le papillon le plus troglophile de notre faune". - Austria: L21 (23 June 2019: 2 specimens), L22 (23 June 2019: 5 specimens). Cave use (in Austria): Shallow diurnal retreat.

Diplodoma laichartingella (Goeze, 1783) Dottedmargin Bagworm, Psychidae. Cave records from: Luxembourg (Werno et al., 2013). - Austria: L21 (23 June 2019), det. P. Buchner, posted on Lepiforum. Cave use: Deep diurnal retreat. 
Parascotia fuliginaria (Linnaeus, 1761) Waved Black, Erebidae: Boletobiinae. Cave records from: no data. - Austria: V3 (12 July 2019), L31 (21 July 2019, photo record K. Bürger). Cave use: Deep diurnal retreat.

Stauropus fagi (Linnaeus, 1758) Lobster Moth, Notodontidae. Cave records from: no data. - Austria: L31 (21 July 2019, photo record K. Bürger). Cave use: Random.

Lymantria monacha (Linnaeus, 1758) Black Arches, Erebidae: Lymantriinae. Cave records from: no data. - Austria: L31 (21 July 2019, photo record K. Bürger). Cave use: Random.

cf. Deileptenia ribeata (Clerck, 1759) Satin Beauty, Geometridae. Cave records from: no data. - Austria: T2 (24 July 2019). Cave use: Random.

Erebia ligea (Linnaeus, 1758) Arran Brown, Nymphalidae. Cave records from: no data. - Austria: T4 (24 July 2019). Cave use: Random.

Nymphalis antiopa (Linnaeus, 1758) Mourning Cloak, Nymphalidae. Cave records from: Hungary (Fazekas, 2001). - Austria: We discovered a pupa in the entrance of Tischoferhöhle: T4 (24 July 2019), det. P. Buchner. Cave use: Random.

Lasiommata maera/petropolitana, Nymphalidae. Reliable determination from the photographs is not possible. Cave records from: no data. - Austria: T7 (24 July 2019). Cave use: Random.

Catocala nupta (Linnaeus, 1767) Red Underwing, Erebidae. Cave records from: Serbia (Jakšić, 2017). Austria: L12 (28 July 2019), L13 (28 July 2019), B8 (28 July 2019, 24 Aug 2019), L25 (10 Aug 2019), L26 (10 Aug 2019), L27 (10 Aug 2019). Cave use: Shallow diurnal retreat.

Autographa gamma (Linnaeus, 1758) Silver Y, Noctuidae: Plusiinae. Cave records from: Hungary (Fazekas, 2001), Italy (Mosconi, 2011). - Austria: L33 (19 Aug 2019). Cave use: Shallow diurnal retreat.

Ecliptopera silaceata (Denis \& Schiffermüller, 1775) Small Phoenix, Geometridae. Cave records from: Italy (Sciarretta et al., 2006; Mosconi, 2011). Austria: S2 (22 Aug 2019, photo record K. Bürger). Cave use: Deep diurnal retreat.

Rheumaptera hastata (Linnaeus, 1758) Argent and Sable, Geometridae. Cave records from: no data. - Austria: S2 (22 Aug 2019, dead specimen, photo record K. Bürger). Cave use: Random.

\section{Temporal increase in Lepidoptera species recorded from caves in Austria}

The cumulative species number of Austrian cave lepidopterans shows an accelerated increase in the years 2015-2019. In the same period of time meteorologists recorded a sharp increase in the number of hot days (Fig. 1).

\section{DISCUSSION}

For many years after 1982 the present authors did not notice any new cave moth in Austria. Starting from 2015, however, unrecorded species emerged in quick succession: 2 spp. in 2015, 1 sp. in 2016, 3 spp. in 2017, 20 spp. in 2018 and 19 spp. in 2019. This steep rise after decades of stagnation, visualized in Figure 1, extended the list of Austrian cave lepidopterans to the current total of 62 species, a number comparable to the inventories of well-investigated countries such as Italy (73 spp.) or Romania (54 spp.) (Centelles Bascuas, 2015).

Almost 4100 Lepidoptera species have been registered in Austria (Huemer, 2013, and subsequent addenda). Like everywhere else, only a fraction have nonrandom relationships with caves. Imagoes of these butterflies and moths enter deep subterranean habitats (sensu Culver \& Pipan, 2014) only exceptionally and are thus elements of the shallow subterranean fauna (Novak et al., 2012) and, in terms of the preferred places in the cave, the parietal association (Jeannel, 1926). The best-known motive

$$
70
$$

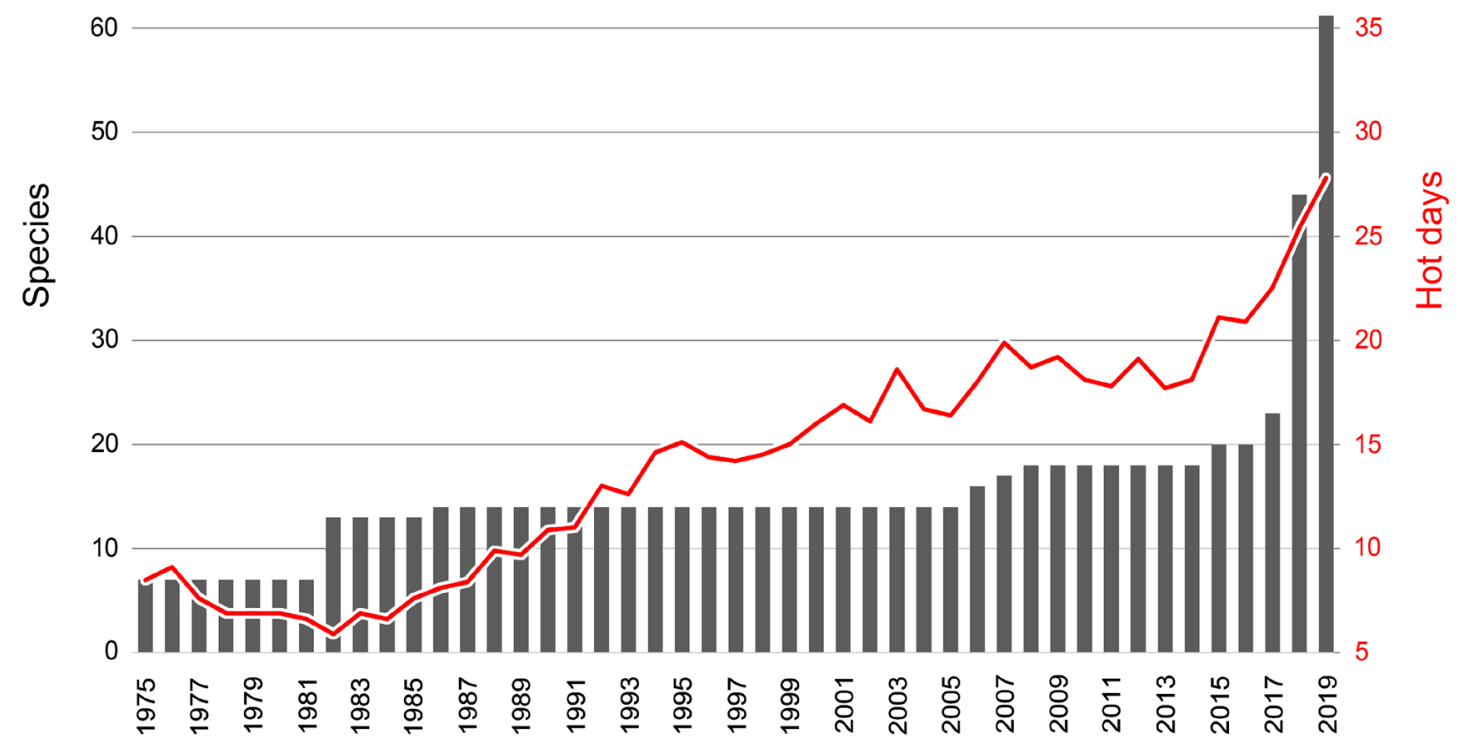

Fig. 1. Cumulative species number of Lepidoptera recorded in caves of Austria plotted against the annual number of hot days ( $\max . \geq 30^{\circ} \mathrm{C}, 10$-year moving average). Climate data, collected at Vienna, Hohe Warte: Central Institute of Meteorology and Geodynamics. 
for temporary cave residence of Lepidoptera is overwintering. Species such as Scoliopteryx libatrix spend a hypogean ecophase in caves or comparable locations where they remain in a dormant state, unaffected by the outer world's weather (Lipovšek et al., 2017). As would seem natural, subtroglophile species of this type first caught the attention of cavers and biospeleologists: The seven species listed by Strouhal \& Vornatscher (1975) are all entering caves for overwintering. Most of the later recorded lepidopterans are either random visitors or take daytime shelter in caves on hot summer days. Among the here newly reported species, overwintering (in addition to aestival daytime retreat) has been shown only for Chloroclysta siterata, Alucita huebneri and Agonopterix heracliana.

Nine of the 62 Austrian cave lepidopteran species seek subterranean places for overwintering, 25 for diurnal retreat, and four display both types of cave use. 24 species are provisionally rated as random cave guests. This supports the view that the trogloxenes constitute a heterogenous cave guild (Parimuchová et al., 2018) even after the detachment of the subtroglophiles. Trogloxenes and subtroglophiles mainly occur in the twilight zone where diel and seasonal changes of environmental conditions (Mammola \& Isaia, 2018) are steeply decreasing towards the interior of the cave. The differentiation of shallow and deep retreat is to account for the different behavior of lepidopterans along this gradient.

Although our inspections did not follow a rigid monitoring protocol, the rapid increase of butterfly and moth species in caves cannot be dismissed as a mere methodological artifact. Effort and diligence of data collection were virtually constant between 1978 and present, with about 80 cave inspections per year. Also during the period of increasing species numbers the frequency did not vary greatly: $89,68,78$, and 87 inspections in the years 2015-2018, repeated visits of the same object counted. Only the 2019 peak of 147 inspections might have produced some bias - the enhanced activity was stimulated by the discoveries of the previous year. Different types of caves were inspected from the beginning of our zoological records, the proportion between natural and artificial objects did not fluctuate much. Likewise the field method remained unchanged over the time period of our analysis: We recorded all visible macrofauna at each cave inspection. The consistent procedure suggests that the recent increase in cave lepidopteran records is the reflection of a real-world phenomenon: In Austria the relations of butterflies and moths to caves have become closer.

Could the increase in cave records be a side effect of growing population density? A survey among lepidopterists revealed that this is obviously not the case. There is no indication of a local or temporal increase in relative abundance of the frequently observed cave guests during the 2010s. Therefore we favor the hypothesis that caves became more attractive diurnal resting places for a variety of butterflies and moths. And we further hypothesize that it is climate warming, particularly the increase in number and magnitude of hot days during the past years, that causes a change in the diurnal refuge preference of certain species of Lepidoptera.

Even the first newly recorded cave moth species made us think in this direction. Euplagia quadripunctaria and Catocala elocata had been known as cave guests in the southern parts of their distribution areas, in warm, mostly Mediterranean countries. As to the night and day active tiger moth E. quadripunctaria, evidence of cave visits in Central Europe was not available, in contrast to several published records in southern regions. The Austrian observations correspond with a French report, which says that in hot weather $E$. quadripunctaria takes refuge at various cool places including cave entrances (Braud \& Sardet, 2013). The same pertains to $C$. elocata which turned out to be the most frequently encountered Austrian cave moth at mid-summer time. This species had been reported from caves in Greece, Bulgaria, Italy and Spain before. Mormo maura exhibits a similar pattern, albeit this species has been detected in cave-like hiding places even in England (Dacie, 1985).

Meteorological data support the hypothesis that the shift in diurnal refuge preference is climatically triggered. The five warmest summers in more than 250 years of continuous temperature recording in Austria have all occurred in the years after 2000, and summer temperatures of 2015,2017, 2018, and 2019 were more than $3.0^{\circ} \mathrm{C}$ above the long-term average (ZAMG, 2019). Of particular significance in our context is the increase of hot summer days from 2015 onwards (Fig. 1). Measurements in various caves with and without moth records corroborate the assumption that many of the here reported lepidopterans are seeking cave mouths for a cool diurnal repose. We found that on hot summer days air temperature can drop by $10^{\circ} \mathrm{C}$ within a few meters behind the eaves line. Profiles of Sulzberghöhle (B8) may serve as an example. We determined air temperature in and around this gently declining cave with a maximum horizontal extension of $35 \mathrm{~m}$ in the early afternoon hours of warm days in three consecutive years. The difference between the immediate exterior and the innermost part of the cave was up to $26.6^{\circ} \mathrm{C}$ (Fig. 2).

Effects of climate warming on butterflies and moths have been studied from the late 1980s onwards (Kocsis \& Hufnagel, 2011). Lepidoptera soon turned out to react by shifts along various axes: changes in abundance, changes in phenology, poleward and upward range expansions or shifts, and physiological and behavioral adaptations (Woiwod, 1997; Bellard et al., 2012). The responses to climate warming are largely species-specific, as shown in our data material by frequent cave records of relatively rare species. The inclination for using cave mouths as sites of diurnal repose differs even among closely related species. $C$. nupta is the most frequent Catocala species in Vienna and western Lower Austria, whereas C. elocata is rare in Vienna and absent in western Lower Austria (Schulze, 2008; Schweighofer, 2013). In terms of cave observations, however, C. elocata is more frequent by a factor of four. 


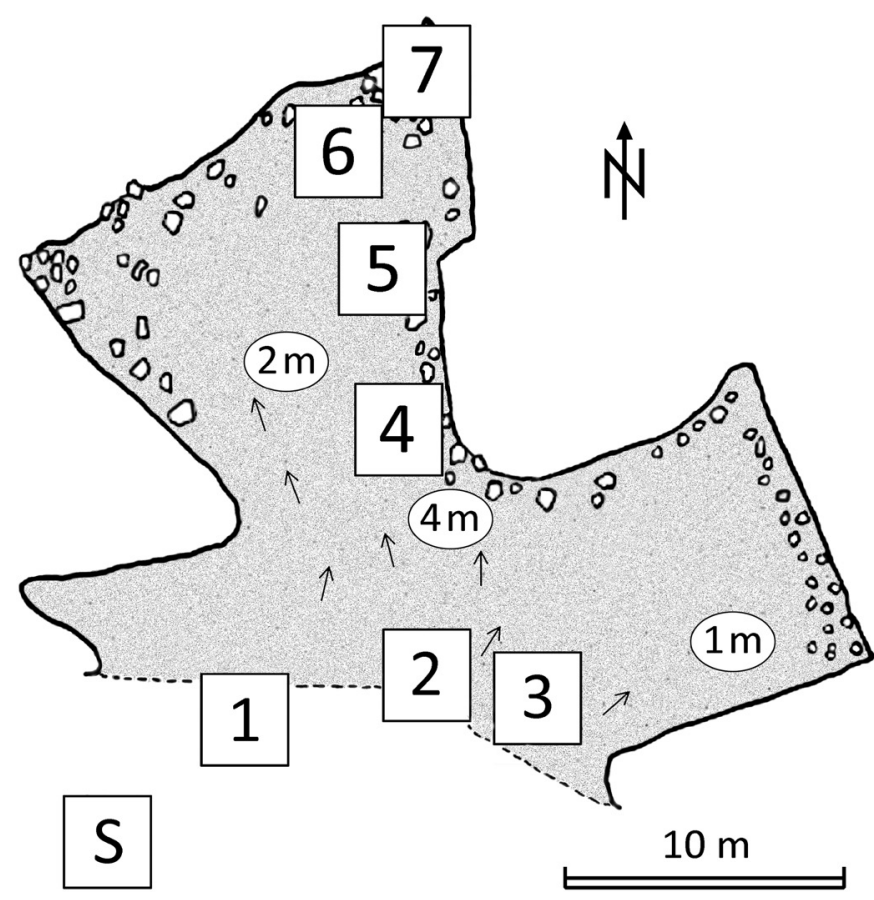

Fig. 2. Temperature transect from the surrounding deciduous forest (S) through Sulzberghöhle (Stotzing, Burgenland). Values $\left({ }^{\circ} \mathrm{C}\right)$ of 09.08.2018/29.07.2019/09.08.2020. (S)..35.1/25.1/27.3,

(1)..31.2/23.7/24.7, (2)..26.0/21.8/22.5, (3)..24.1/21.2/21.9,

(4)..15.3/14.9/14.9, (5)..11.8/11.7/11.8, (6)..8.8/8.8/8.9, (7)..8.5/8.4/8.5

The ascertained shift in diurnal refuge preference is most plausibly explained as a climate-induced adoption of a "southern" life style feature by Central European populations of certain Lepidoptera.

\section{ACKNOWLEDGEMENTS}

We are indebted to Peter Buchner for taxonomic support and to Peter Huemer for information on lepidopteran diversity. Many thanks go to Michaela Zemanek, Melitta Christian, Irene Drozdovski, Ulla Höllwieser, Kevin Moog, Alexander Mrkvicka and Alexander Reischütz for assistance in the field. We thank Katharina Bürger for providing a number of photo-based records, Matthias Kropf and Lukas Plan for photo vouchers, and Erhard Fritsch for record data. The helpful comments of Lubomir Kováč and an anonymous referee are gratefully acknowledged.

Authorship statement: $\mathrm{OM}$ and EC did the field work and analyzed the data. OM and RE surveyed the literature. RE identified most of the lepidopterans and checked previous determinations. OM and EC wrote the manuscript with input from RE.

\section{REFERENCES}

Alberti, B., 1938. Fahrt ins Frankenland II. Internationale Entomologische Zeitschrift, 52, 345-348.

Bellard, C., Bertelsmeier, C., Leadley, P., Thuiller, W., Courchamp, F., 2012. Impacts of climate change on the future of biodiversity. Ecology Letters, 15, 365-377. https://doi.org/10.1111/j.1461-0248.2011.01736.x

Bender, R.,1963. Beiträge zur Lepidopterenfauna der Insel Rhodos. Zeitschrift der Wiener Entomologischen Gesellschaft, 48, 11-20.

Beron, P., 1994. Résultats des recherches biospéléologiques en Bulgarie de 1971 à 1994 et liste des animaux cavernicoles bulgares. Fédération Bulgare de Spéléologie, Sofia, $137 \mathrm{p}$.

Beron, P., Petrov, B., Stoev, P., 2011. The invertebrate cave fauna of the Western Rhodopes (Bulgaria and Greece). In: Beron, P. (Ed.), Biodiversity of Bulgaria. 4. Biodiversity of Western Rhodopes (Bulgaria and Greece) II. Pensoft and National Museum of Natural History, Sofia, p. 583-662.

Beshkov, S., Lanourov, M., 2004. Butterflies and Moths (Insecta: Lepidoptera) of the Bulgarian part of Eastern Rhodopes. In: Beron, P., Popov, A. (Eds.), Biodiversity of Bulgaria. 2. Biodiversity of Eastern Rhodopes (Bulgaria and Greece). Pensoft and National Museum of Natural History, Sofia, p. 525-676.

Beshkov, S., Petrov, B., 1996. A catalogue of the Bulgarian Lepidoptera species reported and collected from the caves and galleries in Bulgaria (Insecta, Lepidoptera). Atalanta, 27, 433-448.

Beshkov, S., Wegner, H., 2004. Macrolepidoptera of the Greek part of the Eastern Rhodopes. In: Beron, P., Popov, A. (Eds.), Biodiversity of Bulgaria. 2. Biodiversity of Eastern Rhodopes (Bulgaria and Greece). Pensoft and National Museum of Natural History, Sofia, p. 677-722.

Braud, Y., Sardet, E., 2013. Les insectes d'intérêt communautaire (DH2) sur le site Natura 2000 "Steppique Durancien et Queyrassin" (FR9301502). Report to the Communauté de communes du Guillestrois, Guillestre, 94 p.

Calle, J.A., 1982. Noctuidos españoles. Ministerio de Agricultura, Pesca y Alimentacion, Madrid, 430 p.

Căpuşe, I., Georgescu, M., 1962. Acrolepia pulicariae Klim. (Acrolepidae, Lep.) un nouvel élément troglophile dans les grottes de la R. P. Roumanie. Bulletin de la Société Entomologique de Mulhouse, 18, 75-78.

Centelles Bascuas, R., 2015. Les papillons des grottes. Essai d'inventaire français et européenet indications bibliographiques. Spelunca, 140, 49-51.

Christian, E., Moog, O., 1982. Zur Frage der ökologischen Klassifikation der Cavernicolen am Beispiel der HöhlenSchmetterlinge Österreichs. Zoologischer Anzeiger, 208, 382-392.

Culver, D.C., Pipan, T., 2009. The biology of caves and other subterranean habitats. Oxford University Press, Oxford, 254 p.

Culver, D.C., Pipan, T., 2014. Shallow subterranean habitats. Ecology, Evolution, and Conservation. Oxford University Press, Oxford, 258 p. https://doi.org/10.1093/acprof:oso/ 9780199646173.001.0001

Curl, R.L., 1964. On the definition of a cave. Bulletin of the National Speleological Society, 26, 1-6.

Dacie, J., 1985. A home for old ladies in Wimbledon. The entomologist's record and journal of variation, 97, 59-62.

Dethier, M. \& Depasse, J., 2004. Les papillons dans le monde souterrain. Bulletin des Chercheurs de la Wallonie, 43, 83-90.

Dew, B., 1963. Cave animals. Journal of the Sydney University Speleological Society, 6, 10-28.

Dobat, K., 1978. Die Höhlenfauna der Fränkischen Alb. Abhandlungen zur Karst- und Höhlenkunde, Reihe D, 3, 1-238.

Dvořák, L., 2000. Notes on hibernation of Lepidoptera species in underground shelters of the Bohemian Forest and of West Bohemia. Silva Gabreta, 5, 167176 (in Czech).

Dvořák, L., 2002. Some results of a research of Lepidoptera in caves of southwest Bohemia and the list of Lepidoptera found in karst caves of both Czech and Slovak republics. Český kras, 28, 9-12 (in Czech). 
Dvořák, L., Belicek, J., Fric, Z., 2009. Observations of overwintering nymphalid butterflies in underground shelters in SW and W Bohemia (Czech Republic) (Lepidoptera: Nymphalidae: Nymphalini). Journal of Research on the Lepidoptera, 41, 45-52.

Ebert, G. (Ed.), 2001. Die Schmetterlinge BadenWürttembergs. Band 8, Nachtfalter VI. Ulmer, Stuttgart, $541 \mathrm{p}$.

Escolà, O., 1982. Primeres dades sobre la collecció de lepidòpters subtroglófils del Museo de Zoologia. II Sessiò Conjunta d'Entomologia ICHN-SCL, Barcelona 1981, 15-24.

Fabbri, R., Poletti, K., 2015. Invertebrati delle cavità dei Gessi di Brisighella e Rontana. Memorie dell'Istituto Italiano di Speleologia, s. II, 28, 341-365.

Fazekas, I., 2001. Butterfly species of the KovácsszénájaiFüstös-lik (SW-Hungary). Folia Comloensis, 10, 83-90 (in Hungarian).

Fritsch, E., 2008. Bericht der Katasterführer mit Vorschau auf 2008. Mitteilungen des Landesvereins für Höhlenkunde in Oberösterreich, 54, 4-5.

Fritsch, E., Greger, W., Pavuza, R., Thaler, H., Cech, P., 2016. Der Rudolfstollen in Linz-Urfahr (Österreich) und seine Umgebung. Eine naturwissenschaftlichhistorische Bestandsaufnahme. Denisia, 38, 1-99.

Guéorguiev, V., Beron, R., 1962. Essai sur la faune cavernicole de Bulgarie. Annales de Spéléologie, 17, 285-441.

Hofsäß, K., no date. http://ftp.funet.fi/index/Tree of life/warp/album-Hofsaess-2.html [accessed: September 22, 2020].

Huemer, P., 2013. Die Schmetterlinge Österreichs (Lepidoptera). Systematische und faunistische Checkliste. Studiohefte 12, Tiroler Landesmuseen, Innsbruck, $304 \mathrm{p}$.

Jakšić, P., 2017. Cave moth and butterfly fauna (Insecta: Lepidoptera) of Serbia: Current state and future prospects. University thought, Publication in Natural Sciences, 7(1), 8-12. https://doi.org/10.5937/univtho7-14038

Jeannel, R., 1926. Faune cavernicole de la France, avec une étude des conditions d'existence dans le domaine souterraine. Lechevalier, Paris, 334 p.

Kerschbaum, W., Pöll, N., 2010. Die Schmetterlinge Oberösterreichs. Teil 5: Geometridae (Spanner). Beiträge zur Naturkunde Oberösterreichs, 20, 1-469.

Kocot-Zalewska, J., Domagała, P., 2020. Terrestrial invertebrate fauna of Polish caves - a summary of 100 years of research. Subterranean Biology, 33, 45-69. https://doi.org/10.3897/subtbiol.33.48805

Kocsis, M., Hufnagel, L., 2011. Impacts of climate change on Lepidoptera species and communities. Applied Ecology and Environmental Research, 9, 43-72. https://doi.org/10.15666/aeer/0901_043072

Kováč, L., Elhottová, D., Mock, A., Nováková, A., Krištůfek, V., Chroňáková, A., Lukešová, A., Mulec, J., Košel, V., Papáč, V., Luptáčik, P., Uhrin, M., Višňovská, Z., Hudec, I., Gaál, L', Bella, P., 2014. The cave biota of Slovakia. State Nature Conservancy SR, Slovak Caves Administration, Liptovský Mikuláš, 191 p.

Kučinič, M., 2002. Lepidoptera. In: Gottstein Matočec, S. (Ed.), An overview of the cave and interstitial biota of Croatia. Natura Croatica, 11, suppl. 1, p. 68.

Lepesme, P., 1937. Hofmannophila pseudospretella Stt. (Lep. Gelechiidae), hôte indésirable des habitations et des magasins. Bulletin de la Société entomologique de France, 42, 283-288.

Lepiforum: Bestimmung von Schmetterlingen (Lepidoptera) und ihren Präimaginalstadien. http:// www.lepiforum.de [accessed: September 22, 2020].
Lipovšek, S., Janžekovič, F., Novak, T., 2017. Ultrastructure of fat body cells and Malpighian tubule cells in overwintering Scoliopteryx libatrix (Noctuoidea). Protoplasma, 254, 2189-2199.

https://doi.org/10.1007/s00709-017-1110-3

Lopez, A, 1997. Observations sur le Lépidoptère souterrain Pyrois effusa Boisduval, 1829 (Noctuidae) et sa biologie sexuelle. Mémoires de Biospéologie, 24, 71-76.

Macdonald, J., 1992. The decomposition of animal remains in caves. Unpublished PhD thesis, Nottingham Polytechnic, Nottingham, 274 p.

Malavasi, L., 2005. https://www.cisonostato.it/viaggio/ italia/il-cilento-minuto-per-minuto-1332.htm [accessed: August12, 2020].

Mammola, S., Isaia, M., 2018. Day-night and seasonal variations of a subterranean invertebrate community in the twilight zone. Subterranean Biology, 27, 31-51. https://doi.org/10.3897/subtbiol.27.28909

Mammola, S., Piano, E., Cardoso, P., Vernon, P., Dominguez-Villar, D., Culver, D.C., Pipan, T., Isaia, M., 2019. Climate change going deep: The effects of global climatic alterations on cave ecosystems. The Anthropocene Review, 6, 98-116.

https://doi.org/10.1177/2053019619851594

Mosconi, F., 2011. Biologia comparata dei principali lepidotteri cavernicoli italiani nella loro ecofase sotteranea. Unpublished $\mathrm{PhD}$ thesis, Sapienza Università di Roma, 137 p.

Mukhanov, A.V., Kapralov, S., 2010. On the fauna of lepidopteran species in caves of the European Russia. Bulletin of the N.I. Lobachevsky University Nizhni Novgorod. General Biology, 2, 439-441 (in Russian).

Novak, T., Perc, M., Lipovšek, S., Janžekovič, F., 2012. Duality of terrestrial subterranean fauna. International Journal of Speleology, 41, 181-188.

https://doi.org/10.5038/1827-806X.41.2.5

Parimuchová, A., Šustr, V., Devetter, M., Vošta, O., Popa, I., Kováč, L., 2018. The activity of saccharolytic enzymes in Collembola is associated with species affinity for caves. International Journal of Speleology, 47, 155163. https://doi.org/10.5038/1827-806X.47.2.2150

Pérez Fernández, T., Yela Yela García, J.L., Lencina Gutiérrez, J.L., 2012. Lepidópteros de las cuevas de Los Chorros y El Farallón (Calar del Río Mundo, Riópar, Albacete, España). Arquivos Entomolóxicos, 7, 197-200.

Rákosy, L., 2004. Lepidoptere din peşterile României. Buletin de informare entomologică, 14-15, 201-206.

Sánchez Piñero, F., Pérez López, F.J., 1998. Coprophagy in Lepidoptera: Observational and experimental evidence in the pyralid moth Aglossa pinguinalis. Journal of Zoology, 244, 357-362. https://doi.org/10.1017/S0952836998003069

Sarlet, L.G., 1982. Des papillons dans les grottes. Natura Mosana, 35, 8-15.

Schön, W., 2020. https://www.schmetterling-raupe.de/ art/siterata.htm [accessed: August 21, 2020].

Schulze, C.H., 2008. Vorkommen und Gefährdungsstatus von Ordensbändern Catocala spp. (Lepidoptera, Noctuidae: Catocalinae) in Wien. Study commissioned by Environmental Protection in Vienna (MA 22), 35 p.

Schweighofer, W., 2013. Ordensbänder im westlichen Niederösterreich. Lanius-Information, 23(3-4), 7-9.

Sciarretta, A., Parenzan, P., Mancini, M., 2006. I lepidotteri cavernicoli in Italia. Thalassia Salentina, 29 (suppl.), 139-158.

Sket, B., 2008. Can we agree on an ecological classification of subterranean animals? Journal of Natural History, 42, 1549-1563.

https://doi.org/10.1080/00222930801995762 
Skinner, B., Wilson, D., 2009. Colour identification guide to the moths of the British Isles: Macrolepidoptera ( $3^{\text {rd }}$ Ed.). Brill, Leiden, 323 p. https://doi.org/10.1163/9789004261020

Slamova, I., Klecka, J., Konvicka, M., 2011. Diurnal behavior and habitat preferences of Erebia aethiops, an aberrant lowland species of a mountain butterfly clade. Journal of Insect Behavior, 24, 230-246. https://doi.org/10.1007/s10905-010-9250-8

Strouhal, H., Vornatscher, J., 1975. Katalog der rezenten Höhlentiere Österreichs. Annalen des Naturhistorischen Museums in Wien, 79, 401-542.

Trimmel, H., 1968. Höhlenkunde. Vieweg, Braunschweig, 300 p. https://doi.org/10.1007/978-3-663-07259-1

Turquin, M.-J., 1994. Lepidoptera. In: Juberthie, C., Decu, V. (Eds.), Encyclopaedia biospeologica, vol. 1. Société de Biospéologie, Moulis \& Bucharest, p. 333-339.

Weichenberger, J., 1989. Das Nixloch bei Losenstein, 1665/1. Mitteilungen des Landesvereins für Höhlenkunde in Oberösterreich, 35, 54-58.
Werno, A., Weber, D., Meyer, M., 2013. Schmetterlinge (Insecta, Lepidoptera) aus Höhlen des Großherzogtums Luxemburg. In: Weber, D. (Ed.), Die Höhlenfauna Luxemburgs. Ferrantia, 69, Musée National D’histoire Naturelle, Luxembourg, 408 p.

Wiklund, C., Tullberg, B.S., 2004. Seasonal polyphenism and leaf mimicry in the comma butterfly. Animal Behaviour, 68, 621-627. https://doi.org/10.1016/j.anbehav.2003.12.008

Woiwod, I. P., 1997. Detecting the effects of climate change on Lepidoptera. Journal of Insect Conservation, 1, 149-158.

https://doi.org/10.1023/A:1018451613970

Young, M., 1997. The Natural History of moths. Poyser, London, $271 \mathrm{p}$.

ZAMG, 2019. https://www.zamg.ac.at [accessed: August 05, 2020].

Zilli, A., 1992. Troglofilia locale in popolazioni appenniniche di Nudaria mundana (Linnaeus, 1761) (Lepidoptera, Arctiidae). Bolletino dell'Associazione Romana di Entomologia, 46 (1991), 65-75. 